\title{
Díaz Alarcón, Soledad; Castillo Bernal, Pilar. Antología poética de voces femeninas del siglo $X X$. Madrid: Sindéresis, 2018, 203 pp., ISBN 978-84-16262-61-8
}

¿Son necesarios los estudios y las antologías de autoras femeninas? ¿Podemos hablar de poesía en femenino? Poullain de la Barre decía "que la mente no tiene sexo", al igual que hoy podemos afirmar que tampoco tiene sexo la literatura, y que, aunque en muchos casos las autoras han quedado fuera de las antologías literarias, afortunadamente existen más estudios y antologías de autoras femeninas que en épocas pasadas. Sin embargo, aún queda mucho camino que hollar en lo que a cánones literarios y currículos educativos se refiere. No obstante, la antología de autoras escogidas que nos presenta Soledad Díaz Alarcón y Pilar Castillo Bernal de la mano de la editorial Sindéresis, más concretamente de escritoras de poesía, va más allá de un simple estudio de perspectiva de género. No cabe duda de que es necesario divulgar la obra femenina y redescubrir escritoras, o en este caso de poetas, que en la mayoría de los casos son desconocidas para los lectores hispanoparlantes pues sus obras ni siquiera fueron traducidas al español y en muchos casos jamás tuvimos constancia de sus voces. Por ello, esta obra adopta una perspectiva mucho más plural y universal en cuanto a temas, voces, aspectos traductológicos e incluso desde el propio ámbito de la lengua, ya que se ocupa de tres lenguas como el alemán, el francés y el inglés, determinantes desde el punto de vista cultural de finales del siglo XIX y $\mathrm{XX}$ que perfilaron los contornos de nuestra historia y nuestro mundo.

Entonces ¿es necesaria una antología de poetas extranjeras traducidas al español? Desde luego que sí, y qué mejor justificación que los versos recogidos de Marie Claire Bancquart que aparecen citados en el primero de los capítulos de este libro, porque según ella, "ser mujer es algo así como nacer siendo ceniza" (p.25), es decir, ser mujer es como nacer con la voz de los muertos, es nacer privadas de la palabra, si se me permite, y así, con versos cargados de simbolismo, fuerza y crudeza, acaso seamos capaces de vislumbrar la situación de estas autoras en su tiempo. Dicho de otro modo, saca de los cajones polvorientos de la nada aquellas voces que habían permanecido relegadas y brillan por su ausencia en traducciones de antologías de poesía. En La mística de la feminidad de Betty Friedman (1963) se identifica el problema sin nombre que viven las mujeres esposas, madres, amas de casa... que a veces no se sienten personas, hasta el punto de que el mundo se olvida de ellas. $Y$ como nos presentan las autoras de esta Antología poética de voces femeninas del siglo $X X$, poco a poco se consiguen cambiar las realidades parciales, sesgadas, retomando los trabajos de 
mujeres que aparecieron a principios del $X X$ en el plano sociocultural de la escritura y que fueron capaces de producir obras interesantes que nos llegan como una muestra escogida en este compendio, pese a haber sido silenciadas por la historia. No olvidemos que, atendiendo a una panorámica global de voces y temas, como en la antología que nos ocupa, podemos atisbar la realidad y la belleza desde diversos puntos de vista, obteniendo una panorámica colorida y compleja de la literatura, la poesía en particular, y el arte en general.

Entonces, ¿por qué acercarse a esta antología poética de voces femeninas? Ya hemos dicho que una de las razones estriba en que permite acercarnos desde todas las perspectivas de la realidad sociocultural que aparece reflejada en la poesía de finales del XIX, principios y mediados del $X X$, a la vez que permite mantener la distancia histórica y temporal para que podamos valorar desde un punto de vista crítico, estético y objetivo las obras que se incluyen. Además, esta colección de poemas acerca la voz dormida de autoras que no nos han llegado como parte del legado literario, que en muchas ocasiones han sido relegadas al cajón de lo irrelevante simplemente por ser mujeres, no porque sus poemas estuvieran exentos de calidad literaria, ya que en algunos casos algunas de ellas gozaron de reconocido prestigio en su época e incluso fueron galardonadas por sus obras. Esta antología es la puerta de entrada a un mundo inexplorado, la llave que nos indica e invita a abrir una cerradura en la inmensidad de la casa de las mil y una puertas. Para aquellos que sientan curiosidad por la calidad de los poemas de las autoras escogidas que se incluyen en la selección que Soledad Díaz Alarcón y Pilar Castillo Bernal nos proponen en esta antología, no me cabe duda de que el lector encontrará la frescura y la sorpresa de descubrir un paraje maravilloso y desconocido, a la par que familiar, con un toque personal por la manera de presentar la temática, la forma y la simbología en cada poema. Será una experiencia como la del paseante solitario que tantas veces ha recorrido el bosque, pero que de pronto se topa con un paraje hermoso, desconocido e inexplorado, un bosque que no era del todo conocido hasta ese momento. Así, encontramos variedad de temas: la guerra, la emancipación, la identidad femenina, la poesía moderna en la que el lenguaje es un interrogante y con el que se experimenta en sí mismo, la creación literaria, las palabras, el amor, la ilusión, la naturaleza, las relaciones familiares, el exilio, la naturaleza, la ausencia, la simplicidad, la espontaneidad, los símbolos, el desengaño...Temas que surgen de experiencias vitales que se dejan traslucir en el producto creado.

Otro punto a favor de esta obra es la forma en la que está estructurada ya que la organización en un prólogo, una introducción general y bloques según la lengua origen, a saber, francés, alemán e inglés, facilita la lectura y 
permite seguir de forma sucinta y sistemática las características clave de cada uno de los bloques en cuanto a espacio-tiempo, vanguardias, movimientos, características estéticas y formales. A cada bloque le precede una breve introducción con las autoras que se incluyen, el panorama histórico literario, los movimientos y las motivaciones que llevaron a escoger a esas autoras y no otras, y una serie de comentarios de traducción con aspectos o puntos relevantes que incluyen problemas, técnicas y estrategias de traducción de los poemas traducidos, breves referencias a las diferencias en traducción poética entre diversas lenguas... para luego dar paso a una breve biografía de cada autora que permite al lector comprender y situar a cada una de ellas y sus obras en contexto. Así mismo, las traducciones aparecen en espejo junto a los originales para que el lector pueda disfrutar del texto original o de la traducción si así lo prefiere. Por todo ello, Antología poética de voces femeninas del siglo $X X$ ofrece una panorámica interesante de las obras que produjeron estas autoras y del marco en el que surgieron. El estilo en el que está escrita esta antología facilita el acercamiento a la poesía y a la traducción de este género a estudiantes, eruditos o de aquellos que se acercan con más reticencia a la poesía. Una obra para todos los que quieran aproximarse al fenómeno de la poesía que además es un catálogo que compendia referencias a diversidad de metros, rimas, estrofas, temas y recursos retóricos morfosintácticos, fónicos y semánticos, en cada uno de los idiomas que incluso puede servir tanto para introducirse como para profundizar en el estudio y análisis de la traducción en poesía, puede utilizarse como material para el estudio de la poesía de finales del XIX y comienzos del XX que muchas veces ha sido obviada de los cánones generales, o puede servir como guía para apreciar el arte de la poesía, e incluso, salvando las distancias, de manual de escritura creativa. Dentro de esta antología, uno de los aspectos más interesantes es la inclusión del enfoque traductor, que contribuye a la difusión de estas autoras y de sus obras, lo cual es interesante desde el punto de vista del aprendizaje y de la comprensión de procesos de traducción para los estudiantes de traducción y de la recepción de las obras, ya que presta especial atención a la esencia de los originales y a la rica simbología que encierran, a la vez que expone los problemas encontrados en la traducción, estrategias y las técnicas de traducción empleadas, así como a las peculiaridades que presenta la traducción poética desde los distintos textos de origen hacia la lengua española. Un trabajo que da habida cuenta de las técnicas a utilizar dependiendo del tipo de autoras que se traducen y la complejidad de sus obras, como por ejemplo en el caso de las autoras de lengua francesa donde se opta por traducciones más próximas a la fidelidad métrica, mientras que en la traducción de las alemanas se ha optado por mantener la simbología y la transmisión semántica. 
Por tanto, acercarse a esta antología es percibir la herencia literaria en conjunto, dejarse imbuir por el sentido polifónico de la poesía, porque como recoge Soledad Díaz Alarcón en su traducción "desde el momento en que las mujeres dejan de ser las ninfas, las musas, los seres etéreos" (p. 26)... y se convierten en hacedoras, en activistas, en escritoras de pleno derecho que empuñan las imágenes y las palabras, que alzan las voces y que son capaces de conjurar los versos más bellos y que en algunos casos desempeñaron un papel importante en el estrato cultural, escritoras, periodistas, conferenciantes, críticas literarias, traductoras, preocupadas por temas universales de calado, que incluso hoy en día siguen preocupándonos, como la naturaleza, los derechos de los animales, la ecología, la guerra, pero también el concepto de amor entre mujeres, la maternidad e incluso la propia creación literaria, por eso es interesante esta antología, porque no aborda exclusivamente una perspectiva de género o una dualidad de roles femeninos y masculinos, sino porque va más allá de las concepciones androcentristas o reduccionistas de la obra. Por otro lado, sería interesante continuar esta colección con otras antologías similares que nos acerquen a más autoras, incluso de escritoras que escribieron en otras lenguas, y que nos muestren más temáticas o incluso otros géneros.

Desde la rigurosidad y sin caer en lo subjetivo, Antología poética de voces femeninas del siglo $X X$ presenta cinco autoras por idioma, recreando una atmósfera clave para entender a cada autora y a cada poema, y nos hace caer en la cuenta de que la poética del siglo XX escrita por mujeres exhibe un corte más extenso que el de lo puramente femenino. Esta poesía es un ser vivo que respira y que se alimenta de temas universales, poemas en los que la poesía se libera, se fragmenta, se deconstruye, se permeabiliza de metros, rimas y de recursos retóricos variados que influyen en la utilización de unas técnicas de traducción u otras y que influyen. Ni un detalle queda a la ligera en esta colección, una cuidada selección de autoras que atiende a criterios temporales que permitan apreciar el sincretismo de movimientos y vanguardias, y que permiten descubrir autoras que gozaron de popularidad en su época pero que al final desaparecieron de la escena. Una obra pormenorizada, multidisciplinar, que combina el interés de los estudios de autoras femeninas, el gusto por la poesía del siglo XX y el enfoque traductor. Un libro para ser leído más de una vez tanto por la riqueza que encierra como por los contenidos, el contexto, la belleza poética, sin olvidar el gusto y cuidado que se aprecia en las traducciones. Bebamos pues del lago de las pupilas (p. 37) y del reflejo de las palabras que nos regalaron estas mujeres, cuyos versos vuelven hoy como un eco, alcanzándonos con su fuerza, donde las palabras son una aproximación de lo que es. Por último, me gustaría concluir esta reseña con autoras que me han sobrecogido sobremanera. La primera de ellas Thérèse Aubray con poemas traducidos de tan bella factura 
como Phénix (p. 64), por las imágenes que evoca, la fuerza que encierra y la cuidada traducción que se nos ofrece, que nos invita a dejarnos inundar por sus versos para que las palabras renazcan de las palabras al igual que el ave fénix. Pero cualquiera de los poemas que se incluyen de esta autora merecen una lectura. Dentro de las escritoras alemanas, podemos citar a Ingeboch Bachmann que recoge un poema muy interesante desde el punto de vista de las palabras y la creación titulado Ihr Worte (p. 114). Por último, dentro de las autoras inglesas, resaltaría el poema de Alice Meynell $A$ Song of Derivations (p. 154) en el que se plantean preguntas metafísicas sobre el origen de lo que somos. Una antología más que recomendable y necesaria.

[MiRIAN SoledAd TRIGueros dE LA Fuente] 